\title{
Impact of Flax Fiber Reinforcement on Mechanical Properties of Solid and Foamed Geopolymer Concrete
}

\author{
Kinga Korniejenko ${ }^{*}$, Michał Łach, Maria Hebdowska-Krupa, Janusz Mikuła \\ Institute of Material Engineering, Faculty of Material Engineering and Physics, Cracow University of Technology, \\ Cracow, Poland
}

Received 18 February 2020; received in revised form 02 June 2020; accepted 25 August 2020

DOI: https://doi.org/10.46604/aiti.2021.5294

\begin{abstract}
The main objective of this study is to develop the advanced composites for civil engineering applications as material for the building industry, especially for an insulation purpose. The research processes include several steps. Firstly, the prototype elements, such as bricks and elevation elements were performed from eco-friendly composite -flax fiber reinforced geopolymer. The elements were designed to take into consideration for environment. Geopolymers are environmentally friendly, sustainable, and resource efficient, including energy demand. Next, the wall was built from these elements and exposed during the three months in a relevant environment. The main conclusion of the research is that the kind of fibers is important for the mechanical properties of the composite, including the fact that for those different fibers could be more beneficial for different raw materials, giving higher strength properties. The significant influence on the mechanical properties of the composites has the adhesion between fiber and material used as a matrix. The adhesion depends among others on the previous treatment of the fibers.
\end{abstract}

Keywords: geopolymer, mechanical properties, foamed material, flax fiber

\section{Introduction}

The background for the article is a pressure for the change of the traditional economy that is based on a linear approach to a so-called circular economy in recent years. The main principle of the circular economy is designing out waste and pollution. The rational management of natural resources and the usage of waste materials are getting more and more important. It is also supported by the growing ecological awareness of society, including the consciousness of sustainable development [1-2]. One of the most promising technologies for a circular economy is the geopolymerization with using waste streams. This technology is dedicated to the construction industry. It has a much lower carbon footprint than the technology of manufacturing traditional construction materials $[1,3]$. The geopolymer synthesis also enables one to use waste, such as mining tiles or industrial by-products as a raw material for manufacturing new products in low energy and low emission processes [4-5].

One of the limitations for the wide usage of this technology in construction industry is the brittle fracture behavior of the received materials and their relatively low tensile as well as flexural strength $[1,6]$. In order to improve tensile and flexural strength, it is possible to reinforce the geopolymer matrix by fibers [2-3]. From a mechanical point of view, reinforcement by fibers is an efficient method to improve material properties, for instance, fracture toughness. The fibers reduce the general effects of cracking, limit the widths of the occurring cracks, especially the propagation of micro-cracks, suppress all brittle

* Corresponding author. E-mail address: kinga.korniejenko@pk.edu.pl

Tel.: +48 609974988 
behavior, and enhance ductility [1,3]. The fibers additions also increase the flexural strength of composites. The fibers improve energy absorption and resistance to deformation [3, 7-9]. In particular, the introduction of short fibers due to their easy fiber dispersion and fiber shape factor; it is an effective way to strengthen geopolymer materials [3].

Currently, the reinforcements used in geopolymer composites are usually based on inorganic fibers, such as carbon or glass fibers [3, 10] or synthetic fibers [11]. However, the new research direction usage of eco-friendly materials is clearly visible. From the environmental point of view, the addition of natural fibers is particularly beneficial [1, 12]. This solution is an environmentally friendly alternative to inorganic fibers $[1,13]$.

Nevertheless, natural fibers usually have lower mechanical properties. It does not always allow their desired applications. Natural fibers have lower dimensional repeatability than artificial fibers, but these fibers have also many advantages [14-15]. The most important features are: reduction of the environmental impact (closing important life cycles, including $\mathrm{CO}_{2}$ ), low cost of production, low density; the fibers are usually renewable in a short time, non-toxic, and easy to process [1, 16]. The research shows natural fibers could replace the conventional ones in many applications; and gives added value, especially reduction of greenhouse gas emissions and negative environmental impacts [1-2].

Contemporary, the flax is one of the most popular fibers used as reinforcement to geopolymer matrix [17]. The research was made on the matrix based on dehydroxylated kaolinite-type clay (New Zealand halloysite - Imerys Premium grade) [18], low calcium fly ash (from the Eraring power station in NSW) [19-20], fly ash with nano-clay particles [21-22]. The flax fibers were added in an amount: 4 - $10 \mathrm{wt} \%$. The research results pointed out that mechanical properties are improved by fiber addition, especially flexural strength $[17,23]$. The other research shows the possibility of using the geopolymers reinforced by short flax fibers in additive manufacturing technology [24-26].

There were several attempts to investigate foamed geopolymers reinforced by fibers. Most of the research was dedicated to reinforcement by artificial fibers such as carbon [27-28] or glass [29-30], including waste products [29-30]. Some of the investigations have been done on the composites with natural fibers such as hemp [31-32], abaca [33], cellulose [34-35] and jute [36]. The mineral fibers; for example, basalt have been also tested [28, 37].

The hemp (Cannabis sativa) fiber is one of the most widely applied cellulosic fibers as reinforcement in different kinds of composites [31]. The two amounts of short hemp fibers were applied 1.13 and $4.53 \%$ [32]. The results show good bonding between matrix and reinforcement, good stability to the thermal variation and improvement of mechanical properties [32].

The research conducted with abaca fibers shows its improving properties [33], including increasing compressive strength and flexural ranged from 19.6 MPa to 36.8 MPa and 2.4 MPa to 6.3 MPa, respectively [33]. The addition of jute fibers also positively influenced on mechanical properties, flame, and water resistance [37].

The investigation with cellulose shows the positive influence of this addition on $\mathrm{pH}$ and the possibility of applying this material for eco-friendly pots [34-35]. The flax fibers in foamed geopolymers were only investigated as an addition to long fibers [36]. The results show the positive effect of the addition to flax fibers on impact bending and flexural strength [38]. Additionally, the flax fibers were compared with basalt fibers (both were added in amount -2.16 wt $\%$ ). The results show a different pattern of failure mechanisms dependent on applied reinforcement [38].

The main purpose of the provided research is to develop the advanced composites for civil engineering applications, as material for the building industry. This paper shows the possibilities of using waste streams coming from energy industry (fly ashes and agriculture waste) and short flax fibers (residues for linen production), as raw materials to produce high-added value lightweight and low thermal conductivity geopolymer composites, including foamed products. These kinds of materials could be used as the advanced composites for civil engineering applications, as a construction material as well as insulation one and also for rehabilitating deteriorated concrete [39]. The previous study does not include semi-industrial tests for the foamed geopolymers reinforced flax fibers [40-41]. 


\section{Materials and Methods}

\subsection{Materials}

Two kinds of materials have been prepared: solid and foamed. The solid geopolymers based on the fly ash from the CHP plant in the city called Skawina (Lesser Poland region, Poland) and sand in ratio 1:1. This fly ash has the physical and chemical properties that support the geopolymerization process [42-44]. The second geopolymers according to the metakaolin and sand in ratio $1: 1$. Both kinds of samples were reinforced with $1 \%$ by mass of flax fibers. In order to reinforce, the following flax fibers were applied as compositions to solid materials:

(1) Raw flax fiber - shortened (raw straw).

(2) Long flax fiber after dew retting.

(3) Cottonized flax fiber.

The foamed materials the following flax fibers were applied to:

(1) Cottonized flax fiber - internal layer.

(2) Shortened flex fiber after water retting - external and internal layer.

(3) Short flax fiber - external layer.

\subsection{Samples preparation}

Samples were prepared using sodium promoter, fly ash or metakaolin, sand, and various flax fibers (each $1 \%$, by mass of the composite). The process of activation has been made by a 10M sodium hydroxide solution combined with the sodium silicate solution (liquid glass at a ratio of 1:2.5). The geopolymers were produced using technical sodium hydroxide flakes and an aqueous sodium silicate solution of R-145 (module 2.5 ), with a molar density of about $1.45 \mathrm{~g} / \mathrm{cm}^{3}$. The tap water was used instead of the distilled one. In the case of the foamed plated, the hydrogen peroxide has been used - $3.5 \%$ for metakaolin and $2 \%$ for fly ash based geopolymers. The alkaline solution was prepared by pouring the aqueous solution of sodium silicate over the solid sodium hydroxide. The solution was mixed and allowed to equilibrate until a constant concentration and temperature were achieved. It took nearly 2 hours. The fly ash or metakaolin, sand, alkaline solution, and fibers were mixed for about 15 minutes by using a low-speed mixing machine (to receive the homogeneous paste). On this stage for the foamed materials, a proper amount of hydrogen peroxide was introduced and continuously mixed for approximately 1 min. After the mixing process was complete, the material was poured into a mold and exposed to a temperature of $75{ }^{\circ} \mathrm{C}$ for 24 hours. After the heating process, the elements were dismantled and stored under laboratory conditions for a period of 28 days to obtain the full strength.

The following kind of samples were prepared (Table 1. and Table 2.):

(1) Bricks-solid material

- Metakaolin with a cottonized flax fibre.

- Metakaolin with a long flax fibre after dew retting.

- Metakaolin with a raw flax fibre - shortened (raw straw).

- Fly ash (FA) with a cottonized flax fibre.

- FA with a raw flax fibre-shortened (raw straw).

The detailed information about composition of prepared samples - solid bricks is included in Table 1 . 
Table 1 Composition of the solid samples - bricks

\begin{tabular}{|c|c|}
\hline No. & Sample \\
\hline 1 & Metakaolin with a cottonized flax fiber \\
\hline 2 & Metakaolin with a long flax fiber after dew retting \\
\hline 3 & Metakaolin with a raw flax fiber - shortened (raw straw) \\
\hline 4 & Fly ash (FA) with a cottonized flax fiber \\
\hline 5 & FA with a raw flax fiber - shortened (raw straw) \\
\hline
\end{tabular}

(2) Elevation plates-the internal layer (solid material, ca. $1 \mathrm{~cm}$ ) and external layer (foamed material, ca. $4 \mathrm{~cm}$ ) A sketch of the elevation plate are presented in Fig. 1:

- External layer: metakaolin with the shortened flex fibre after water retting, internal layer: metakaolin with the shortened flex fibre after water retting (metakaolin: sand ratio - 0.85:0.15, hydrogen peroxide - 3.5\%).

- External layer: FA with the short flax fibre, internal layer: FA with the cottonized flax fibre (FA: sand ratio - 0.75:0.25, hydrogen peroxide $-2.0 \%$ ).

- External layer: FA with the shortened flex fibre after water retting, internal layer: FA with a shortened flex fibre after water retting (FA: sand ratio - 0.85:0.15, hydrogen peroxide - 2.0\%).

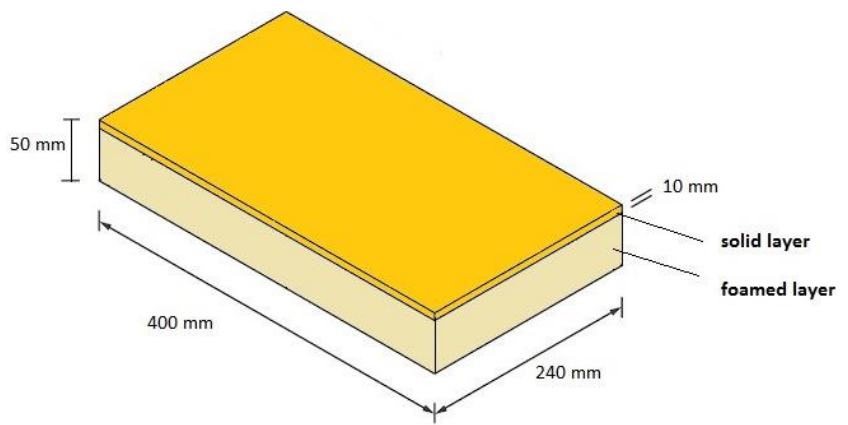

Fig. 1 Sketch of the elevation plate

The detailed information about composition of prepared samples-elevation plates is included in Table 2.

Table 2 Composition of the elevation plates

\begin{tabular}{|c|c|c|c|}
\hline No. & Sample - external layer & Sample - internal (foamed) layer & $\mathrm{H}_{2} \mathrm{O}_{2}$ \\
\hline 1 & $\begin{array}{c}\text { Metakaolin with a shortened flex fiber } \\
\text { after water retting }\end{array}$ & $\begin{array}{c}\text { Metakaolin with a shortened flex fiber after water } \\
\text { retting (metakaolin: sand ratio - 0.85:0.15) }\end{array}$ & $3.5 \%$ \\
\hline 2 & FA with a short flax fiber & $\begin{array}{c}\text { FA with a cottonized flax fiber (FA: sand ratio - } \\
0.75: 0.25 \text { ) }\end{array}$ & $2.0 \%$ \\
\hline 3 & $\begin{array}{c}\text { FA with a shortened flex fiber after } \\
\text { water retting }\end{array}$ & $\begin{array}{c}\text { FA with a shortened flex fiber after water retting } \\
\text { (FA: sand ratio - 0.85:0.15) }\end{array}$ & $2.0 \%$ \\
\hline
\end{tabular}

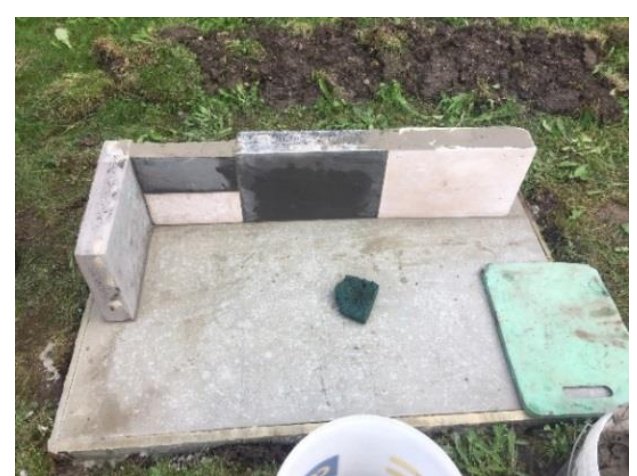

Fig. 2 The wall made from bricks and elevation plates - first layer

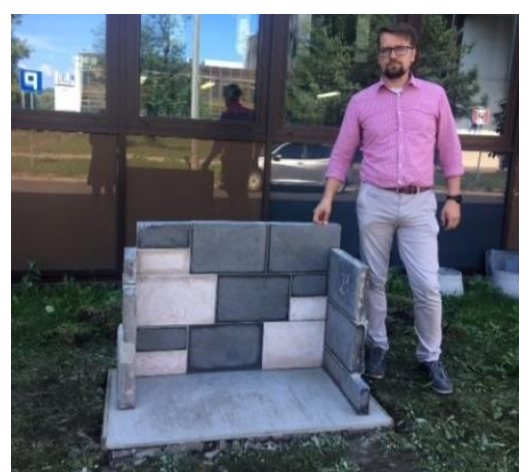

Fig. 3 The wall made from bricks and elevation plates build on the university campus

The both prototype solutions are presented in Fig. 2 - bricks (small elements) and elevation plates (large elements). In Fig.

2, there were two solid bricks-lower based on metakaolin (white color), upper-based on fly ash (gray color). The brick size was: 
$25 \mathrm{~cm} \times 12 \mathrm{~cm} \times 5 \mathrm{~cm}$. The plate's size was: $40 \mathrm{~cm} \times 24 \mathrm{~cm} \times 5 \mathrm{~cm}$ (Fig. 1). The gray elevation plates based on the fly ash reinforced by flax fibers and white elevation plates based on metakaolin reinforced by flax fibers are also shown in Fig. 2 (right site).

Eventually, the two products have been used for creating the prototype wall (Fig. 3) for testing in a relevant environment. The wall was placed on the campus of the Cracow University on Technology (Jana Pawła II Street, Cracow) and left on the open-air for 3 months. Next, it was demolished and the chosen parts were investigated according to mechanical properties.

\subsection{Methods}

Compressive strength tests were carried out according to the methodology described in the standard EN 12390-3 ('Testing hardened concrete. Compressive strength of test specimens'), because of the lack of separate standards for geopolymer materials. The tests involved cubic samples: $50 \times 50 \times 50 \mathrm{~mm}$. The samples have been cut from large plates previously prepared (wall elements). Tests were performed on a concrete press - MATEST 3000kN with speed of 0.5 [MPa/s].

Bending tests were carried out according to the methodology described in the standard EN 12390-5 ('Testing hardened concrete. Flexural strength of test specimens'), because of the lack of separate standards for geopolymer materials. The tests involved prismatic samples: $50 \times 50 \times 200 \mathrm{~mm}$ (space between supporting points $150 \mathrm{~mm}$ ). The samples have been cut from large plates previously prepared (wall elements). Tests were performed on a universal testing machine-MATEST 3000kN with speed of $0.05 \mathrm{MPa} / \mathrm{s}$. The calculations were based on the following equation:

$$
f_{c f}=\frac{F l}{d_{1} d_{2}^{3}}
$$

Where 3

$$
\begin{aligned}
& \mathrm{f}_{\mathrm{cf}} \text { - compressive strength, } \mathrm{MPa} \\
& \mathrm{F} \text { - maximal load, } \mathrm{N} \\
& \text { L - space between supporting points, } \mathrm{mm} \text { (for conducted tests: } 140 \mathrm{~mm} \text { ) } \\
& \mathrm{d}_{1}, \mathrm{~d}_{2} \text { - sample dimensions, } \mathrm{mm}
\end{aligned}
$$

\section{Experimental Results and Discussion}

\subsection{Compressive strength}

The results of the compressive strength tests are shown in Table 3 and Table 4.

Table 3 Results of compressive strength tests: bricks-solid material

\begin{tabular}{|c|c|c|}
\hline No. & Sample & MPa \\
\hline 1 & Metakaolin with a cottonized flax fiber & 66.4 \\
\hline 2 & Metakaolin with a long flax fiber after dew retting & 67.6 \\
\hline 3 & Metakaolin with a raw flax fiber - shortened (raw straw) & 42.9 \\
\hline 4 & FA with a cottonized flax fiber & 58.0 \\
\hline 5 & FA with a raw flax fiber - shortened (raw straw) & 90.8 \\
\hline
\end{tabular}

The tests were provided on minimum of 6 samples. The compressive strength test results achieved for bricks (solid material) were between 42.9 to $90.8 \mathrm{MPa}$. The received values for all types of materials are better than for conventional concrete. The best results were achieved for a fly ash based geopolymer with the raw flax fiber - 90.8 MPa. The results were drastically different than for the geopolymer concrete based on the metakaolin with the raw flax fiber-shortened (raw straw) - 
$1 \%$ by mass. In the case of the cottonized flax fiber, better results were received for the metakaolin basedmatrix than for fly ash based one. The reverse results were achieved for composites reinforced by raw straw fibers. The better results were for fly ash based geopolymer than metakaolin based material.

The investigation was also provided on elevation plates that consist of the foamed material. The plates included elevation part with the solid material and foamed one - isolation layer (Fig. 4). The grey elements are elevation plates based on the fly ash reinforced by flax fibers in Fig. 4. There are visible fibers agglomeration (marked in red arrow). The agglomeration is probably the consequence of not effective mixing process during material manufacturing. It could have an influence on material properties. The white elevation plates based on the metakaolin reinforced by flax fibers are also shown in Fig. 4 . The layers have been produced with similar materials but based on the metakaolin. The material was also reinforced by flax fibers. The plates did not need additional join between the layers - geopolymer binder bounded them.

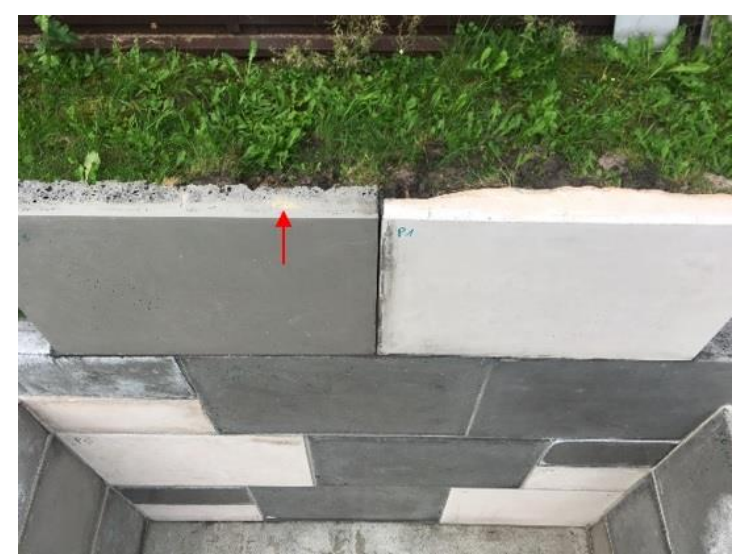

Fig. 4 The elevation plates with visible layers and agglomeration of fibers

The mechanical properties for foamed samples are presented in Table 4.

Table 4 Results of compressive strength tests: elevation plates - foamed material

\begin{tabular}{|c|c|c|c|c|}
\hline No. & Sample - external layer & Sample - internal (foamed) layer & $\mathrm{H}_{2} \mathrm{O}_{2}$ & $\mathrm{MPa}$ \\
\hline 1 & $\begin{array}{c}\text { Metakaolin with a shortened flex fiber } \\
\text { after water retting }\end{array}$ & $\begin{array}{l}\text { Metakaolin with a shortened flex fiber after water } \\
\text { retting (metakaolin: sand ratio }-0.85: 0.15 \text { ) }\end{array}$ & $3.5 \%$ & 6.8 \\
\hline 2 & FA wi & $\begin{array}{c}\text { FA with a cottonized flax fiber (FA: sand ratio - } \\
0.75: 0.25)\end{array}$ & $2.0 \%$ & 6.9 \\
\hline 3 & $\begin{array}{l}\text { FA with a shortened flex fiber after } \\
\text { water retting }\end{array}$ & $\begin{array}{l}\text { FA with a shortened flex fiber after water retting } \\
\text { (FA: sand ratio }-0.85: 0.15)\end{array}$ & $2.0 \%$ & 4.3 \\
\hline
\end{tabular}

The mechanical properties of foamed materials are much lower than solid ones. The same mechanism is presented for all formed materials. The results of compressive strength tests for elevation plates are in range: 4.3 - 6.9 MPa. The lowest results of compressive strength are for the geopolymer concrete based on fly ash with the shortened flex fiber after water retting - $1 \%$ by mass. It is almost $38 \%$ lower than for other investigated materials based on the metakaolin and fly ash. The pours in foamed layers are open.

\subsection{Flexural strength}

The results of the flexural strength tests are shown in Table 5 and Table 6 . The best results were achieved for geopolymer concrete based on the metakaolin with different fibers. This value is definitely better than for traditional cements.

As the same as in the case of compressive strength, the foamed materials have much lower properties than solid ones. The flexural strength test results for bricks were between 7.2 and 10.7. The highest value was received for the metakaolin with the cottonized flax fiber - 10.7 MPa. The results of flexural strength tests for elevation plates are in the range $0.05-0.86 \mathrm{MPa}$. However, the results are comparable or even better than other foamed materials accessible on the market, especially foamed organic polymers. The provided research did not show any deterioration process. 
Table 5 Results of flexural strength tests: bricks - solid material

\begin{tabular}{|c|c|c|}
\hline No. & Sample & $\mathrm{MPa}$ \\
\hline 1 & Metakaolin with a cottonized flax fiber & 10.7 \\
\hline 2 & Metakaolin with a long flax fiber after dew retting & 10.6 \\
\hline 3 & Metakaolin with a raw flax fiber - shortened (raw straw) & 7.2 \\
\hline 4 & FA with a cottonized flax fiber & 7.6 \\
\hline 5 & FA with a raw flax fiber - shortened (raw straw) & 9.4 \\
\hline
\end{tabular}

Table 6 Results of flexural strength tests: elevation plates - foamed material

\begin{tabular}{|c|c|c|c|c|}
\hline No. & Sample - external layer & Sample - internal (foamed) layer & $\mathrm{H}_{2} \mathrm{O}_{2}$ & $\mathrm{MPa}$ \\
\hline 1 & $\begin{array}{c}\text { Metakaolin with a shortened flex fiber } \\
\text { after water retting }\end{array}$ & $\begin{array}{c}\text { Metakaolin with a shortened flex fiber after water } \\
\text { retting (metakaolin: sand ratio - 0.85:0.15) }\end{array}$ & $3.5 \%$ & 0.86 \\
\hline 2 & FA with a short flax fiber & $\begin{array}{c}\text { FA with a cottonized flax fiber (FA: sand ratio - } \\
0.75: 0.25)\end{array}$ & $2.0 \%$ & 0.05 \\
\hline 3 & $\begin{array}{c}\text { FA with a shortened flex fiber after } \\
\text { water retting }\end{array}$ & $\begin{array}{c}\text { FA with a shortened flex fiber after water retting } \\
\text { (FA: sand ratio - 0.85:0.15) }\end{array}$ & $2.0 \%$ & 0.65 \\
\hline
\end{tabular}

\subsection{The effect of flax fibers addition}

The article presents the impact of flax fiber reinforcement on the mechanical properties of solid and foamed geopolymer concrete. The prototype elements such as bricks (made from the solid material) and elevation elements (plates including solid and foamed parts) were manufactured and investigated. The two kinds of raw materials have been tested (fly-ash and metakaolin). The research on the mechanical properties compressive and flexural strength were conducted.

The compressive strength results for the new materials (solid) were between 42.9 and $90.8 \mathrm{MPa}$. These values were achieved for the samples with the raw flax fibers - shortened (raw straw). The results depended on used raw materials. The other tendency was observed for the samples reinforced by the cottonized flax fibers. In this case, the material based on the metakaolin had a higher compressive strength - 66.4 MPa, compared with the samples where fly ash was applied as a raw material - 58.0 MPa. The same tendency was noticed in the results of the flexural strength test. For the samples reinforced by the raw flax fibers-shortened (raw straw), better results were achieved for the material based on fly ash - 9.4 MPa than for based on the metakaolin - 7.2 MPa. The behavior of the material reinforced by cottonized flax fibers for the flexural strength test was similar to the results of the compressive strength test. The composite based on the metakaolin had higher values for the flexural strength - 10.7 MPa than the material based on fly ash - 7.6 MPa.

It shows that the kind of fiber is important for the mechanical properties of the composite, including the fact that for the different raw materials different fibers could be more advantages. The significant influence in this case has the adhesion between the matrix and reinforcement. The adhesion is depended among others on the previous treatment of the fibers. The significant meaning could have also the reaction between fiber and material used as a matrix.

The elevation elements (plates including solid and foamed parts) reinforced by the shortened flex fiber after water retting were also compared. The plates based on the metakaolin have better mechanical properties than based on the fly ash. The values for the plates based on the metakaolin were 6.8 MPa for compressive strength and $0.86 \mathrm{MPa}$ for flexural strength. For the composition based on the fly ash, the relevant values were 4.3 MPa and $0.65 \mathrm{MPa}$, respectively. The different amount of hydrogen peroxide applied in these compositions was not consider, but a larger amount of hydrogen peroxide was added to the material based on the metakaolin; therefore, this material should potentially have lower mechanical properties.

\section{Conclusions}

The research shows the possibility of manufacturing the products for construction industry based on the eco-friendly materials. The composites comprise the waste flax fiber and the reinforced geopolymer concrete. The geopolymers includes 
the fly ash as well as the metakaolin. The new products were designed to take into consideration for environment, including the energy efficiency, reduction of carbon footprint, waste reduction, and development of a circular economy.

The new composites have comparable properties with the results achieved for traditional foamed and solid building materials. The main conclusion of the research is the kind of fibers is important for the mechanical properties of the composite, including the fact that for that different fibers could be more beneficial for different raw materials, giving higher strength properties. The significant influence on the mechanical properties of the composites has the adhesion between fiber and material used as a matrix. The adhesion depends among others on the previous treatment of the fibers.

The contemporary research gives promising results, but further research is required. The practice applications need further tests to optimize the mechanical properties of the composites as well as investigate the other properties such as water absorption and resistance for a different environments, including long-durability issues. The LCA analysis of the chosen products will be also desirable.

\section{Acknowledgement}

This work has been financed by the National Centre for Research and Development in Poland under the grant: Low thermal conductivity geopolymer foams produced with industrial wastes as an innovative material for circular economy (LIDER/31/0168/L-10/18/NCBR/2019) and the ERANet-LAC 2nd Joint Call (http://www.eranet-lac.eu) within the framework of the grant: Development of eco-friendly composite materials based on geopolymer matrix and reinforced with waste fibers.

\section{Conflicts of Interest}

The authors declare no conflict of interest.

\section{References}

[1] K. Korniejenko, E. Frączek, E. Pytlak, and M. Adamski, "Mechanical Properties of Geopolymer Composites Reinforced with Natural Fibers," Procedia Engineering, vol. 151, pp. 388-393, August 2016.

[2] K. Korniejenko, M. Łach, N. Doğan-Sağlamtimur, G. Furtos, and J. Mikuła, "Fibre Reinforced Geopolymer Composites A Review," 1st International Conference on Environment, Technology and Management (ICETEM), June 2019, pp. 3-13.

[3] K. Korniejenko, "The Influence of Short Fibres on the Properties of Composites with Geopolymer Matrix," (in Polish) Ph.D. dissertation, Faculty of Mechanical Engineering, Cracow University of Technology, Cracow, Poland, 2018.

[4] R. M. Novais, J. Carvalheiras, M. P. Seabra, R. C. Pullar, and J. A. Labrincha, "Innovative Application for Bauxite Residue: Red Mud-Based Inorganic Polymer Spheres as pH Regulator,” Journal of Hazardous Materials, vol. 358, pp. 69-81, September 2018.

[5] R. M. Novais, G. Ascensão, N. Ferreira, M. P. Seabra, and J. A. Labrincha, "Influence of Water and Aluminum Powder Content on the Properties of Waste-Containing Geopolymer Foams," Ceramics International, vol. 44, no. 6, pp. 6242-6249, April 2018.

[6] R. A. Sá Ribeiro, M. G. Sá Ribeiro, and W. M. Kriven, “A Review of Particle and Fiber-Reinforced Metakaolin-Based Geopolymer Composites,” Journal of Ceramics Science and Technology, vol. 8, no. 3, pp. 307-322, August 2017.

[7] G. Furtos, L. Silaghi-Dumitrescu, P. Pascuta, C. Sarosi, and K. Korniejenko, "Mechanical Properties of Wood Fiber Reinforced Geopolymer Composites with Sand Addition,” Journal of Natural Fibers, vol. 1, pp. 1-12, June 2019.

[8] A. R. Sakulich, "Reinforced Geopolymer Composites for Enhanced Material Greenness and Durability," Sustainable Cities and Society, vol. 1, no. 4, pp. 195-210, December 2011.

[9] R. Chen, S. Ahmari, and L. Zhang, "Utilization of Sweet Sorghum Fiber to Reinforce Fly Ash-Based Geopolymer," Journal of Material Science, vol. 49, no. 6, pp. 2548-2558, December 2013.

[10] T. Lin, D. Jia, P. He, and M. Wang, "In Situ Crack Growth Observation and Fracture Behavior of Short Carbon Fiber Reinforced Geopolymer Matrix Composites,” Materials Science and Engineering: A, vol. 527, no. 9, pp. 2404-2407, April 2010. 
[11] L. Yan, B. Kasal, and L. Huang, "A Review of Recent Research on the Use of Cellulosic Fibres, Their Fibre Fabric Reinforced Cementitious, Geo-Polymer and Polymer Composites in Civil Engineering,” Composites Part B: Engineering, vol. 92, pp. 94-132, May 2016.

[12] A. M. Rashad, "A Synopsis about the Effect of Basalt and Natural Fibers on Geopolymer Properties," Natural Resources Conservation and Research, vol. 1, pp. 1-9, 2018.

[13] G. Silva, S. Kim, R. Aguilar, and J. Nakamatsu, "Natural Fibers as Reinforcement Additives for Geopolymers-A Review of Potential Eco-Friendly Applications to the Construction Industry," Sustainable Materials and Technologies, vol. 23, e00132, April 2020.

[14] H. Assaedi, F. U. A. Shaikh, and I. M. Low, "Effect of Nanoclay on Durability and Mechanical Properties of Flax Fabric Reinforced Geopolymer Composites,” Journal of Asian Ceramic Societies, vol. 5, no. 1, pp. 62-70, March 2017.

[15] T. Alomayri, F. U. A. Shaikh, and I. M. Low, "Thermal and Mechanical Properties of Cotton Fabric-Reinforced Geopolymer Composites,” Journal of Material Science, vol. 48, no. 19, pp. 6746-6752, June 2013.

[16] F. Pacheco-Torgal and S. Jalali, "Cementitious Building Materials Reinforced with Vegetable Fibers: A Review," Construction and Building Materials, vol. 25, no. 2, pp. 575-582, February 2011.

[17] K. Korniejenko, M. Lach, M. Hebdowska-Krupa, and J. Mikuła, “The Mechanical Properties of Flax and Hemp Fibres Reinforced Geopolymer Composites,” IOP Conference Series: Materials Science and Engineering, vol. 379, 012023, May 2018.

[18] M. Alzeer and K. MacKenzie, "Synthesis and Mechanical Properties of Novel Composites of Inorganic Polymers (Geopolymers) with Unidirectional Natural Flax Fibres (Phormium Tenax),” Applied Clay Science, vol. 75-76, pp. 148-152, May 2013.

[19] H. Assaedi, T. Alomayri, F. U. A. Shaikh, and I. M. Low, "Synthesis and Mechanical Properties of Flax Fabric Reinforced Geopolymer Composites," Advances in Materials Research, vol. 3, no. 3, pp. 151-161, October 2014.

[20] H. Assaedi, T. Alomayri, F. U. A. Shaikh, and I. M. Low, "Characterisation of Mechanical and Thermal Properties in Flax Fabric Reinforced Geopolymer Composites,” Journal of Advanced Ceramics, vol. 4, no. 4, pp. 272-281, 2015.

[21] H. Assaedi, F. U. A. Shaikh, and I. M. Low, "Characterizations of Flax Fabric Reinforced Nanoclay-Geopolymer Composites," Composites Part B: Engineering, vol. 95, pp. 412-422, June 2016.

[22] H. Assaedi, F. U. A. Shaikh, and I. M. Low, "Effect of Nanoclay on Durability and Mechanical Properties of Flax Fabric Reinforced Geopolymer Composites,” Journal of Asian Ceramic Societies, vol. 5, no. 1, pp. 62-70, March 2017.

[23] G. Silva, S. Kim, A. Castañeda, R. Donayre, J. Nakamatsu, R. Aguilar, et al., "A Comparative Study of Linen (Flax) Fibers as Reinforcement of Fly Ash and Clay Brick Powder Based Geopolymers," IOP Conference Series: Materials Science and Engineering, vol. 416, 012107, 2018.

[24] K. Korniejenko, M. Łach, S. Y. Chou, W. T. Lin, J. Mikuła, D. Mierzwiński, et al., "A Comparative Study of Mechanical Properties of Fly Ash-Based Geopolymer Made by Casted and 3D Printing Methods," IOP Conference Series: Materials Science and Engineering, vol. 660, 012005, 2019.

[25] K. Korniejenko, M. Łach, S. Y. Chou, W. T. Lin, A. Cheng, M. Hebdowska-Krupa, et al., "Mechanical Properties of Short Fiber-Reinforced Geopolymers Made by Casted and 3D Printing Methods: A Comparative Study,” Materials, vol. 13, no. 3, 579, January 2020.

[26] K. Korniejenko and M. Łach, "Geopolymers Reinforced by Short and Long Fibres - Innovative Materials for Additive Manufacturing," Current Opinion in Chemical Engineering, vol. 28, pp. 167-172. June 2020.

[27] J. H. Lee, S. Wattanasiriwech, and D. Wattanasiriwech, "Preparation of Carbon Fiber Reinforced Metakaolin Based-Geopolymer Foams,” Key Engineering Materials, vol. 766, pp. 19-27, April 2018.

[28] R. Krzywoń, J. Hulimka, A. Jędrzejewska, and M. Górski, “Application of Fibre Composite Grids as Reinforcement of Foamed PC and GP Concrete," MATEC Web of Conferences, vol. 274, 05002, 2019.

[29] R. M. Novais, R. C. Pullar, and J. A. Labrincha, “Geopolymer Foams: An Overview of Recent Advancements,” Progress in Materials Science, vol. 109, 100621, April 2020.

[30] L. Senff, R. M. Novais, J. Carvalheiras, and J. A. Labrincha, "Eco-Friendly Approach to Enhance the Mechanical Performance of Geopolymer Foams: Using Glass Fibre Waste Coming from Wind Blade Production," Construction and Building Materials, vol. 239, 117805, April 2020.

[31] E. A. Correia, S. M. Torres, M. E. O. Alexandre, K. C. Gomes, N. P. Barbosa, and S. D. E. Barros, "Mechanical Performance of Natural Fibers Reinforced Geopolymer Composites,” Materials Science Forum, vol. 758, pp. 139-45, June 2013.

[32] B. Galzerano, A. Formisano, M. Durante, F. Iucolano, D. Caputo, and B. Liguori, "Hemp Reinforcement in Lightweight Geopolymers," Journal of Composite Materials, vol. 52, no. 17, pp. 2313-2320, November 2017. 
[33] J. P. S. Ngo and M. A. B Promentilla, "Development of Abaca Fiber-Reinforced Foamed Fly Ash Geopolymer," MATEC Web of Conferences, vol. 156, 05018, March 2018.

[34] M. Szechyńska-Hebda, J. Marczyk, C. Ziejewska, N. Hordyńska, J. Mikuła, and M. Hebda, “Optimal Design of pH-Neutral Geopolymer Foams for their Use in Ecological Plant Cultivation Systems,” Materials, vol. 12, no. 18, 2999, September 2019.

[35] M. Szechyńska-Hebda, J. Marczyk, C. Ziejewska, N. Hordyńska, J. Mikuła, and M Hebda, "Neutral Geopolymer Foams Reinforced with Cellulose Studied with the FTRaman Spectroscopy," IOP Conference Series: Materials Science and Engineering, vol. 706, no. 1, 012017, November 2019.

[36] G. Silva, J. Salirrosas, G. Ruiz, S. Kim, J. Nakamatsu, and R. Aguilar, "Evaluation of Fire, High-Temperature and Water Erosion Resistance of Fiber-Reinforced Lightweight Pozzolana-Based Geopolymer Mortars,” IOP Conference Series: Materials Science and Engineering, vol. 706, no. 1, 012016 , November 2019.

[37] V. S. Le, P. Hájková, V. Kovacic, T. Bakalova, V. Lukáš, C. H. Le, et al., "Thermal Conductivity of Reinforced Geopolymer Foams," Ceramics-Silikáty, vol. 63, no. 4, pp. 365-373, 2019.

[38] M. Frydrych, Š. Hýsek, L. Fridrichová, V. S. Le, M. Herclík, M. Pechociaková, et al., "Impact of Flax and Basalt Fibre Reinforcement on Selected Properties of Geopolymer Composites," Sustainability, vol. 12, no. 1, 118, 2020.

[39] R. V. Upadhyaya and T. G. Suntharavadivel, "Optimization of Flyash and Metakaolin Content in Mineral Based CFRP Retrofit for Improved Sustainability,” International Journal of Engineering and Technology Innovation, vol. 9, no. 3, pp. 171-181, July 2019.

[40] N. Ranjbar and M. Zhang, "Fiber-Reinforced Geopolymer Composites: A Review," Cement and Concrete Composites, vol. 107, 103498, March 2020.

[41] G. Bumanis, L. Vitola, I. Pundiene, M. Sinka, and D. Bajare, "Gypsum, Geopolymers, and Starch-Alternative Binders for Bio-Based Building Materials: A Review and Life-Cycle Assessment,” Sustainability, vol. 12, no. 14, 5666, 2020.

[42] K. Korniejenko, N. P. Halyag, and G. Mucsi, "Fly Ash as a Raw Material for Geopolymerisation - Chemical Composition and Physical Properties," IOP Conference Series: Materials Science and Engineering, vol. 706, no. 1, 012002, November 2019.

[43] K. Korniejenko, M. Łach, J. Marczyk, C. Ziejewska, N. P. Halyag, and G. Mucsi, "Fly Ash as a Raw Material for Geopolymerisation-Mineralogical Composition and Morphology," IOP Conference Series: Materials Science and Engineering, vol. 706, no. 1, 012006, November 2019.

[44] M. Łach, J. Mikuła, W. T. Lin, P. Bazan, B. Figiela, K. Korniejenko, "Development and Characterization of Thermal Insulation Geopolymer Foams Based on Fly Ash,” Proceedings of Engineering and Technology Innovation, vol. 16, pp. 23-29, August 2020.

Copyright $\odot$ by the authors. Licensee TAETI, Taiwan. This article is an open access article distributed under the terms and conditions of the Creative Commons Attribution (CC BY-NC) license (https://creativecommons.org/licenses/by-nc/4.0/). 